\title{
Determination of Heavy Metals in Nairobi Dam Water, (Kenya)
}

\author{
Ndeda, L. A. ${ }^{1 *}$, Manohar, S. ${ }^{1}$ \\ ${ }^{I}$ Department of Environmental Sciences, Kenyatta University, Kenya. P.O Box 43844,00100, Nairobi, Kenya.
}

\begin{abstract}
Heavy metals concentrations in Nairobi dam water were analysed between the wet and dry seasons. Water samples were collected once in a month from seven sampling sites within Nairobi dam, these samples were preserved, stored and analysed for heavy metals: Copper (Cu), Cadmium (Cd), Lead $(\mathrm{Pb})$ and Nickel (Ni) concentrations using an Atomic Absorption Spectrophotometer (APHA). The sequence of heavy metals accumulation in dam's water was: $\mathrm{Pb}>\mathrm{Cd}>\mathrm{Cu}>\mathrm{Ni}$, these metals mean values during the dry vs. wet seasons were: $16.78 \pm 0.21$ vs $11.67 \pm 0.21 ; 5.12 \pm 0.18$ vs $3.76 \pm 0.15 ; 4.90 \pm 0.25$ vs $2.99 \pm 0.05 ; 2.11 \pm 0.12$ vs $1.20 \pm 0.13 \mathrm{mg} / \mathrm{L}$ respectively within water of Nairobi dam. These levels of heavy metals in this dam are higher than maximum permissible levels by WHO, EU and KEBS for drinking water. The outlet water had significantly lower metals contamination in comparison to the inlet waters of the dam $(p \leq 0.006)$ during the wet than dry season. It is concluded that higher levels of heavy metals concentration in the dam's water is in the dry than wet season $(p<0.0001)$. Based on water analysis data it is recommended that the water of this dam is not suitable for human consumption and even for agricultural activities.
\end{abstract}

Keywords: Water, Heavy metals, Nairobi dam

\section{Introduction}

Contamination of heavy metals in surface water systems may be either due to natural or anthropogenic activities. The discharge of toxic heavy metals in water bodies is a serious pollution problem affecting water quality especially in wetlands and other water masses due to their toxicity and bio accumulative effect, creating a direct hazard to human health [1]. Heavy metals pollutants in surface water may pose a health risk and can be very harmful if present in drinking water and translocated to food chains. These metals disturb growth, development, reduce haemoglobin, create cancer, damage the body organs and the nervous system, and in extreme cases death of living organisms [2,3].

All heavy metals exist in surface waters in colloidal, particulate, and dissolved phases, although dissolved concentrations are generally low [4]. The solubility of trace metals in surface waters is predominately controlled by the water $\mathrm{pH}$, the type and level of ligands on which the metal could adsorb, and the oxidation state of the mineral components and the redox environment of the system [5].

An assessment of heavy metals concentrations in the surface water of Bompai-jakara drainage basin, Kano State, northern Nigeria, revealed that the annual levels of $\mathrm{Cr}>\mathrm{Fe}>\mathrm{Zn}>\mathrm{Cu}>\mathrm{Pb}$ during the dry than wet seasons but were not statistically significant at $\mathrm{P} \geq 0.05$. All these five elements analyzed had concentrations above WHO and American Water Works Association standard limit for effluents discharge into surface waters [6]. It has been reported that the differences in geography and geologies, as well as activities in various rivers affects the amount of metals present $[7,8]$. "Heavy metals cannot be degraded they are continuously being deposited and incorporated in water, sediments and aquatic organisms." [9]

The purpose of this study was to analyse the levels of heavy metals in water, and to monitor the water quality of Nairobi dam (Kenya) during wet and dry seasons. Kibera is the largest slum dwellings in Africa on the North eastern bank of Nairobi dam (Kenya). It is an informal settlement by all standards, and a major contributor to pollution of the Motoine-Ngong river (Fig. 1) mostly due to large quantities of waste emanating from unserviced households, solid and liquid waste, including human waste dumped into trenches that drain into the river, and flows into Nairobi Dam [10]. This results to bio-concentrations and biomagnifications which causes potential ecological imbalances and direct health hazards to local people who depend on the water and products from the resource; and especially residents of Kibera informal settlement adjacent to the dam, who are utilizing water from this resource for domestic and commercial purposes.

\section{Materials And Methods}

\section{Study Area}

The study was carried out at Nairobi dam, in Nairobi, Kenya (Fig. 1). The dam is situated at a latitude of $1^{\circ} 19^{\prime}\left(1.3167^{\circ}\right)$ south; longitude of $36^{\circ} 48^{\prime}\left(36.8^{\circ}\right)$ east and has an average elevation of 1,686 meters (5,531 feet) above the sea level. The capacity of this dam is $98,422 \mathrm{cu}$. metres of water and it covers surface area of about $356,179 \mathrm{~m}^{2}$ 


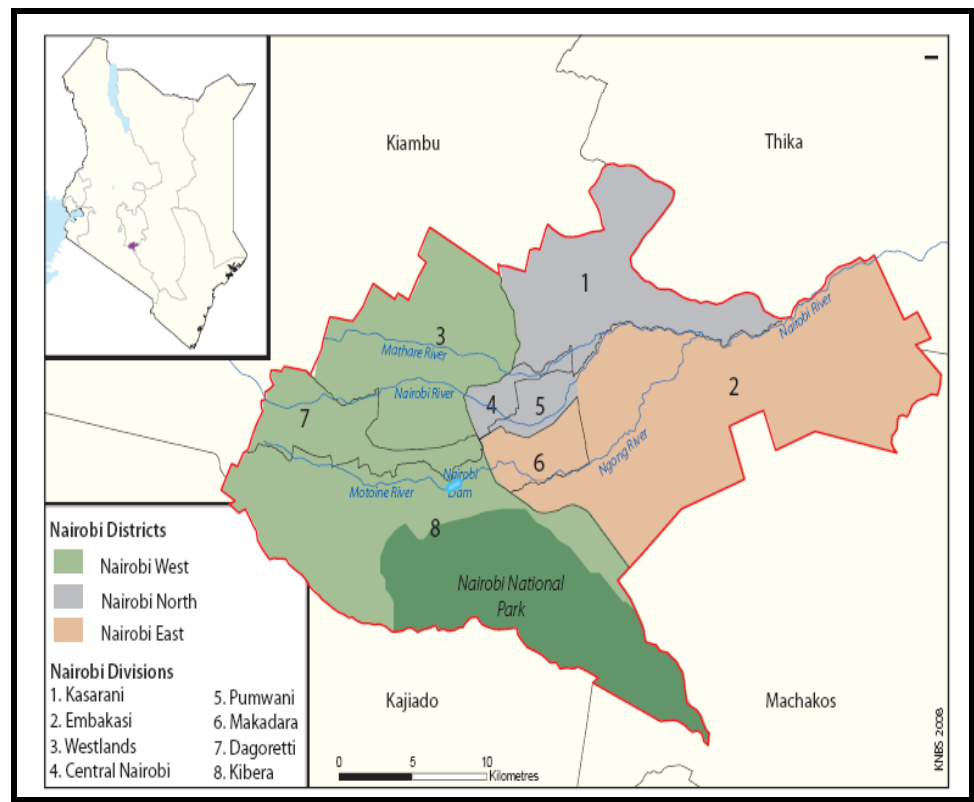

Figure 1: Map of Kenya showing study area i.e. Nairobi Dam

\section{Data Collection and Analysis}

The samples of water from inlet, outlet and also from within the dam were collected from seven sampling stations ( $\mathrm{n}=7)$ : $\left(1^{\text {st }}\right.$ sample station was $10 \mathrm{~m}$ before the stream dropping in Nairobi dam; $2^{\text {nd }}$ station was at a distance of $5 \mathrm{~m}$ after the discharge; $3^{\text {rd }}$ station was $5 \mathrm{~m}$ inwards of the west shore; $4^{\text {th }}$ station was $5 \mathrm{~m}$ inwards of the outlet, $5^{\text {th }}$ station was $5 \mathrm{~m}$ inwards of the east shore; $6^{\text {th }}$ station was approximately in the centre of the dam, and the $7^{\text {th }}$ station was $1 \mathrm{~m}$ from the outlet stream of Nairobi dam). Clean labelled polypropylene plastic bottles [11] were used to collect samples. Water samples were collected once in a month from a depth of $0.5 \mathrm{~m}$ from the surface of the selected seven stations, during the wet season (November 2012 to early January 2013) and during the dry season (February to early April 2013). These water samples were transported to chemical laboratory and preserved with $1.5 \mathrm{ml} / \mathrm{L}$ analar Conc. $\mathrm{HNO}_{3}$. The water samples were digested in Conc. $3 \mathrm{HNO}_{3}: \mathrm{HCl}$ [11]. Shimadzu flame Atomic Absorption spectrophotometer (AA-630) was used in the determinations of heavy metals $(\mathrm{Pb}, \mathrm{Cu}, \mathrm{Cd}, \mathrm{Ni})$ [11]. Data analysis includes statistical summaries (mean and standard error values at each sampling site, from 1 to 7 ; and independent $\mathrm{T}$-test at $\alpha=0.05$ ).

\section{Results And Discussion}

\section{Heavy Metals Concentrations in Nairobi Dam Water During Wet and Dry Seasons}

Analysis of dam's water showed that higher concentrations of $\mathrm{Cu}, \mathrm{Cd}, \mathrm{Pb}$ and $\mathrm{Ni}$ were in the dry season with mean values of $4.90,5.12,16.78$ and $2.11 \mathrm{mg} / \mathrm{L}$ as compared to the wet season mean values of 2.99 , $3.76,11.67$ and $1.20 \mathrm{mg} / \mathrm{L}$ respectively (Fig. 2). This was due to increase in temperature and high rate of evaporation during the dry season, resulting to high concentrations of these heavy metals in the dam water. The rainy (wet) season caused a dilution factor in the water body, therefore, low concentrations of these heavy metals were recorded in the dam's water.

Similar results were obtained by Nairobi River Basin Project-Phase II, [12] that the wet weather metal ions concentrations in rivers water were low as compared to dry season levels due to dilution from increased river flow from surface run-off. A study on heavy metals in water at a freshwater wetland in Central Gujarat, India concluded that higher levels of $\mathrm{Cd}, \mathrm{As}$ and $\mathrm{Pb}$ were in water during the dry compared to wet season, due to high rates of evaporation of water during pre monsoon, however after heavy rainstorm their concentrations reduced [13].

It was evident from the results (Fig. 2) that the order of heavy metals concentrations was $\mathrm{Pb}>\mathrm{Cd}>\mathrm{Cu}$ $>\mathrm{Ni}$. Lead $(\mathrm{Pb})$ concentrations in the samples were approximately three times the concentration of $\mathrm{Cd}$ and $\mathrm{Cu}$ and about eight times those of $\mathrm{Ni}$. The concentrations of $\mathrm{Cd}$ in the samples were slightly higher than those of $\mathrm{Cu}$ in both seasons. This suggests that Nairobi dam environs are contaminated with these heavy metals in the order: $\mathrm{Pb}>\mathrm{Cd}>\mathrm{Cu}>\mathrm{Ni}$. Several observed socio-economic and waste dumping activities upstream and from Kibera slums adjacent to the dam includes agriculture, car garages, industries, construction works, car washing, human waste, raw sewage and garbage which are major sources of heavy metal accumulations in the dam. 


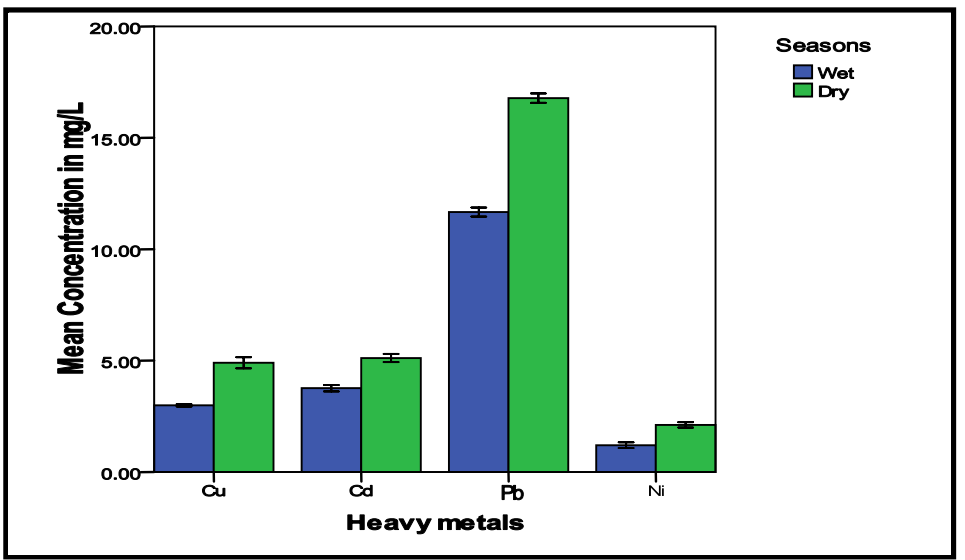

Figure 2: Heavy metals concentrations in the water of Nairobi dam, Kenya

Analysis of heavy metals in water of Madivala Lakes of Bangalore, Karnataka state of India revealed that the order of levels of heavy metals were: $\mathrm{Pb}>\mathrm{Cr}>\mathrm{Cd}>\mathrm{Ni}$ in the water's of the lake [14]. Assessment of heavy metals pollution in water in the northern delta lakes, Egypt [15] showed that metals concentrations in water were in the order: $\mathrm{Fe}>\mathrm{Mn}>\mathrm{Pb}>\mathrm{Zn}>\mathrm{Cu}>\mathrm{Cd}$ in Lake Edku, whereas the order was: $\mathrm{Fe}>\mathrm{Mn}>\mathrm{Pb}>$ $\mathrm{Zn}>\mathrm{Cu}>\mathrm{Cd}$ in Lake Borollus and in Lake Manzala, metals were in the order: $\mathrm{Fe}>\mathrm{Mn}=\mathrm{Cu}>\mathrm{Zn}>\mathrm{Pb}>\mathrm{Cd}$. The sequences of metals concentrations in the three Lakes were: $\mathrm{Fe}>\mathrm{Mn}>\mathrm{Cu}>\mathrm{Zn}>\mathrm{Pb}>\mathrm{Cd}$.

\section{Variations of Heavy Metal(s) in Water at Different Sampling Sites Within Nairobi Dam During Wet and Dry Seasons}

From the results presented in Table 1, during the wet season the dam's water had the highest levels of $\mathrm{Cu}$, $\mathrm{Cd}, \mathrm{Pb}$ and $\mathrm{Ni}$ at site $5(3.18 \mathrm{mg} / \mathrm{L})$, site $1(4.61 \mathrm{mg} / \mathrm{L})$, site $3(12.35 \mathrm{mg} / \mathrm{L})$ and site $3(1.79 \mathrm{mg} / \mathrm{L})$ respectively. However, in the wet season the lowest level of $\mathrm{Cu}$ was at site $4(2.62 \mathrm{mg} / \mathrm{L})$, while those of $\mathrm{Cd}, \mathrm{Pb}$ and $\mathrm{Ni}$ were in site 7 at $(2.89 \mathrm{mg} / \mathrm{L}),(10.16 \mathrm{mg} / \mathrm{L})$ and $(0.28 \mathrm{mg} / \mathrm{L})$ respectively. During the dry season (Table 1$)$ maximum levels of $\mathrm{Cu}, \mathrm{Cd}, \mathrm{Pb}$ and $\mathrm{Ni}$ in dam's water were at site $3(5.72 \mathrm{mg} / \mathrm{L})$, site $1(6.18 \mathrm{mg} / \mathrm{L})$, site $3(17.51 \mathrm{mg} / \mathrm{L})$ and site $1(2.65 \mathrm{mg} / \mathrm{L})$ respectively. Minimum level of $\mathrm{Cd}$ was at site $4(4.04 \mathrm{mg} / \mathrm{L})$, whereas those of $\mathrm{Cu}, \mathrm{Pb}$ and $\mathrm{Ni}$ were at site $7(3.10 \mathrm{mg} / \mathrm{L}, 15.22 \mathrm{mg} / \mathrm{L}$ and $1.11 \mathrm{mg} / \mathrm{L})$ respectively. There were reduced levels of all the heavy metals in site 2 compared to site 1 , for instance during the wet season $\mathrm{Cu}$ level at site 2 was $2.95 \mathrm{mg} / \mathrm{L}$ against $3.07 \mathrm{mg} / \mathrm{L}$ at site 1 . Higher levels of heavy metals were in site 3 compared to site 6 during wet and dry seasons.

These results suggest that high levels of heavy metals pollution in dam's water were at site 1, 3 and 5 while reduced levels were in site 4 and 7. This may be due to large quantities of solid and liquid waste disposed in the dam from Kibera slum adjacent to site 3 and the activities including garages, carwash, agriculture and sewage flowing into the dam along site 1 and 5. Reduced levels of these heavy metals near the outlet and at the outlet (site 4 and 7) may be due to pollution removal mechanisms within the wetland. There were significant differences $(\mathrm{p}<0.05)$ in heavy metal's $(\mathrm{Cu}, \mathrm{Cd}, \mathrm{Pb}$ and $\mathrm{Ni})$ accumulation in dam's water within the different sampling sites 1 to 7 during the wet and dry seasons (Table 1). This may be attributed to varying human activities and ecological characteristics at different sampling sites.

Speciation of heavy metals in water of Asunle River, Nigeria [16] revealed that total heavy metals concentrations in water from different sampling sites within the river varied, mean $\mathrm{Zn}, \mathrm{Pb}, \mathrm{Cu}, \mathrm{Co}, \mathrm{Cd}$ and $\mathrm{Ni}$ levels were $(1.35,0.03,1.10,0.05,0.02$ and $0.22 \mu \mathrm{g} / \mathrm{mL})$ in site $\mathrm{O} ;(2.96,0.07,2.68,0.10,0.06$ and $0.55 \mu \mathrm{g} / \mathrm{mL})$ in site $\mathrm{A} ;(2.35,0.06,2.35,0.08,0.05$ and $0.44 \mu \mathrm{g} / \mathrm{mL})$ in site $\mathrm{B} ;(1.98,0.05,2.00,0.08,0.04$ and $0.33 \mu \mathrm{g} / \mathrm{mL})$ in site C; $(1.68,0.05,1.68,0,07,0.03$ and $0.30 \mu \mathrm{g} / \mathrm{mL})$ in site D respectively. Site O reflected the least levels of heavy metals while A had the highest levels indicating a direct input of heavy metals from the dumpsite. Also, there was a general decrease in the levels of total metals downstream from A to D.

In all the seven sampling sites $(\mathrm{n}=7)$ (Table 1$)$, levels of heavy metals $(\mathrm{Cu}, \mathrm{Cd}, \mathrm{Pb}, \mathrm{Ni})$ were significantly higher in dry than wet season $(\mathrm{p} \leq 0.042)$. The overall mean of $\mathrm{Cu}, \mathrm{Cd}, \mathrm{Pb}$ and $\mathrm{Ni}$ concentrations in dam's water were significantly higher in dry than wet season $(p<0.0001)$. This is due to high evaporation rate during the dry season which resulted to higher concentrations of heavy metals in dam's water compared to dilution in wet season. A study on heavy metals in water in an aquatic ecosystem of tropical industrial region, (India) [17] concluded that comparatively low value for all metals were recorded during rainy season compared to summer, which is due to dilution by addition of rain water and subsequent outflow of reservoir water. Analysis of heavy metals in water of lower River Niger in North Central Nigeria, [18] attributed the high levels of $\mathrm{Zn}, \mathrm{Cr}, \mathrm{Cu}, \mathrm{Mn}$ and $\mathrm{Ni}$ in rivers water during dry than wet season to be due to decrease in the rivers water in the dry season resulting to increase in concentration of the metals in water. 
Table 1: Analysis of heavy metal(s) concentrations in Nairobi dam water collected from seven sampling sites in wet and dry seasons

\begin{tabular}{|c|c|c|c|c|}
\hline Heavy metal(s) & Sampling Site(s) & $\begin{array}{r}\text { Wet season } \\
\text { (Mean } \pm \text { SE) } \mathrm{mg} / \mathrm{L}\end{array}$ & $\begin{array}{r}\text { Dry season } \\
\text { (Mean } \pm \text { SE) } \mathrm{mg} / \mathrm{L} \\
\end{array}$ & p-value \\
\hline \multirow{8}{*}{$\mathrm{Cu}$} & 1 & $3.07 \pm 0.06$ & $5.55 \pm 0.14$ & $<0.0001$ \\
\hline & 2 & $2.95 \pm 0.07$ & $5.36 \pm 0.12$ & $<0.0001$ \\
\hline & 3 & $3.17 \pm 0.12$ & $5.72 \pm 0.32$ & 0.002 \\
\hline & 4 & $2.62 \pm 0.09$ & $3.33 \pm 0.12$ & 0.010 \\
\hline & 5 & $3.18 \pm 0.09$ & $5.66 \pm 0.23$ & 0.001 \\
\hline & 6 & $3.10 \pm 0.08$ & $5.59 \pm 0.29$ & 0.001 \\
\hline & 7 & $2.82 \pm 0.13$ & $3.10 \pm 0.09$ & 0.040 \\
\hline & Mean & $2.99 \pm 0.05$ & $4.90 \pm 0.25$ & $<0.0001$ \\
\hline \multirow{8}{*}{$\mathrm{Cd}$} & 1 & $4.61 \pm 0.25$ & $6.18 \pm 0.20$ & 0.008 \\
\hline & 2 & $4.41 \pm 0.24$ & $6.00 \pm 0.22$ & 0.008 \\
\hline & 3 & $4.12 \pm 0.13$ & $5.23 \pm 0.09$ & 0.002 \\
\hline & 4 & $3.23 \pm 0.16$ & $4.04 \pm 0.09$ & 0.012 \\
\hline & 5 & $3.59 \pm 0.26$ & $5.13 \pm 0.08$ & 0.005 \\
\hline & 6 & $3.48 \pm 0.22$ & $5.10 \pm 0.07$ & 0.002 \\
\hline & 7 & $2.89 \pm 0.12$ & $4.12 \pm 0.33$ & 0.024 \\
\hline & Mean & $3.76 \pm 0.15$ & $5.12 \pm 0.18$ & $<0.0001$ \\
\hline \multirow{8}{*}{$\mathrm{Pb}$} & 1 & $12.12 \pm 0.14$ & $17.19 \pm 0.13$ & $<0.0001$ \\
\hline & 2 & $12.24 \pm 0.14$ & $17.31 \pm 0.16$ & $<0.0001$ \\
\hline & 3 & $12.35 \pm 0.15$ & $17.51 \pm 0.11$ & $<0.0001$ \\
\hline & 4 & $10.35 \pm 0.12$ & $15.43 \pm 0.10$ & $<0.0001$ \\
\hline & 5 & $12.23 \pm 0.14$ & $17.38 \pm 0.12$ & $<0.0001$ \\
\hline & 6 & $12.23 \pm 0.13$ & $17.44 \pm 0.10$ & $<0.0001$ \\
\hline & 7 & $10.16 \pm 0.10$ & $15.22 \pm 0.10$ & $<0.0001$ \\
\hline & Mean & $11.67 \pm 0.20$ & $16.78 \pm 0.21$ & $<0.0001$ \\
\hline \multirow{8}{*}{$\mathrm{Ni}$} & 1 & $1.60 \pm 0.20$ & $2.65 \pm 0.15$ & 0.014 \\
\hline & 2 & $1.39 \pm 0.19$ & $2.47 \pm 0.20$ & 0.018 \\
\hline & 3 & $1.79 \pm 0.10$ & $2.31 \pm 0.12$ & 0.029 \\
\hline & 4 & $0.57 \pm 0.16$ & $1.71 \pm 0.16$ & 0.008 \\
\hline & 5 & $1.51 \pm 0.27$ & $2.39 \pm 0.12$ & 0.042 \\
\hline & 6 & $1.26 \pm 0.12$ & $2.16 \pm 0.11$ & 0.005 \\
\hline & 7 & $0.28 \pm 0.15$ & $1.11 \pm 0.23$ & 0.038 \\
\hline & Mean & $1.20 \pm 0.13$ & $2.11 \pm 0.12$ & $<0.0001$ \\
\hline
\end{tabular}

Mean \pm SE value with $p<0.05$ are significantly different $(\alpha=0.05$, independent T-test $)$

In all the sampling sites $(n=7)$ (Table 1) during both the wet and dry seasons, the levels of heavy metals $\mathrm{Cu}, \mathrm{Cd}, \mathrm{Pb}$ and $\mathrm{Ni}$ in Nairobi dam are in excess of tolerable levels for drinking water based on WHO; EU; and KEBS [3,19,20] standards (Appendix I). Similar results were reported on assessment of the water quality status of Sasumua Watershed, (Kenya) which revealed that for both dry and wet seasons most parameters analysed at Ming'utio River were above WHO standards. Exaggerated levels of potassium, iron, lead, manganese, $\mathrm{pH}$ and turbidity were found; the levels of $\mathrm{Fe}, \mathrm{Pb}, \mathrm{Mn}$ in the wet season were $1.84 ; 0.06 ; 0.87 \mathrm{mg} / \mathrm{L}$ vs. those in dry season of 18.46; 0.23; and $4.00 \mathrm{mg} / \mathrm{L}$, respectively [21].

A study on heavy metal concentrations in water samples around tejgaon industrial area of (Bangladesh) showed that heavy metals concentrations at different sampling points varied in different seasons and the maximum amounts were observed in the dry season. Total $\mathrm{Fe}, \mathrm{Pb}, \mathrm{Cd}, \mathrm{Mn}, \mathrm{Ni}, \mathrm{Zn}, \mathrm{Cu}$ and $\mathrm{Cr}$ concentrations in water samples during dry season ranged from $0.11-2.78,0.733-2.171,0.05-0.1,0.019-0.34,0.02-0.17$, $0.01-0.348,0.10-0.846$, and $0.02-0.09 \mathrm{mg} / \mathrm{L}$ respectively [22]. It was also noted that according to WHO guidelines, during both wet and dry seasons, $100 \%$ water samples were found in the group of "in excess of tolerable level" for $\mathrm{Pb}$ and $95 \%$ water samples were found in the group of 'in excess of tolerable level' for $\mathrm{Cu}$, $\mathrm{Ni}, \mathrm{Cd}, \mathrm{Cr}$ and Mn during dry season [22].

\section{Levels of Heavy Metals Variations in the Inlet and Outlet Water of Nairobi Dam During Wet and Dry Seasons}

Table 2 shows that during the wet season the levels of $\mathrm{Cu}, \mathrm{Cd}, \mathrm{Pb}, \mathrm{Ni}$ in the inlet vs. outlet water of the dam were 3.07 vs $2.82,4.61$ vs $2.89,12.12$ vs. $10.16,1.60$ vs $0.28 \mathrm{mg} / \mathrm{L}$ respectively. In the dry season these heavy metals levels within the inlet vs. outlet water were 5.55 vs $3.10,6.18$ vs $4.12,17.19$ vs $15.22,2.65$ vs $1.11 \mathrm{mg} / \mathrm{L}$ respectively. This shows that during both wet and dry seasons the levels of heavy metals were lower in the outlet water compared to the inlet water of the dam. Therefore, this dam has heavy metals retention capability. A toxicological evaluation that employed an in situ chironomus bioassay at the inlet and outlet of a constructed wetland in South Africa revealed 89\% reduction in toxicity [23]. Similar findings were reported by Schiffer [24] that 26 of 40 water quality variables, such as $\mathrm{Al}, \mathrm{Pb}$ and $\mathrm{Zn}$, were significantly different between the inlet, outlet, near, intermediate, and far sites (with respect to the inlet) of the wetland; these contaminations reduced with distance from the inlet. Heavy metals accumulated in the inlet and outlet water in the order: $\mathrm{Pb}>$ $\mathrm{Cd}>\mathrm{Cu}>\mathrm{Ni}$ in wet and dry seasons (Table 2). This suggests the sequence of heavy metals contamination in the dam's inlet and outlet waters. It also indicates that $\mathrm{Pb}$ is the highest and $\mathrm{Ni}$ lowest retained metal in the wetland. 
Table 2: Comparison of heavy metal's concentrations in the inlet and outlet waters of Nairobi dam during wet and dry seasons

\begin{tabular}{lrrrr}
\hline Parameter & Season(s) & $\begin{array}{r}\text { Inlet } \\
(\text { Mean } \pm \mathbf{S E}) \mathbf{m g} / \mathbf{L}\end{array}$ & $\begin{array}{r}\text { Outlet } \\
(\text { Mean } \pm \text { SE)mg/L }\end{array}$ & p-value \\
\hline $\mathbf{C u}$ & Wet & $3.07 \pm 0.06$ & $2.82 \pm 0.13$ & 0.167 \\
& Dry & $5.55 \pm 0.14$ & $3.10 \pm 0.09$ & $<0.0001$ \\
$\mathbf{C d}$ & Wet & $4.61 \pm 0.25$ & $2.89 \pm 0.12$ & 0.004 \\
& Dry & $6.18 \pm 0.20$ & $4.12 \pm 0.33$ & 0.006 \\
$\mathbf{P b}$ & Wet & $12.12 \pm 0.14$ & $10.16 \pm 0.18$ & $<0.0001$ \\
& Dry & $17.19 \pm 0.13$ & $15.22 \pm 0.10$ & $<0.0001$ \\
& Wet & $1.60 \pm 0.20$ & $0.28 \pm 0.15$ & 0.006 \\
& Dry & $2.65 \pm 0.15$ & $1.11 \pm 0.23$ & 0.005 \\
\hline
\end{tabular}

Mean \pm SE value with $p<0.05$ are significantly different $(\alpha=0.05$, independent T-test $)$

The levels of $\mathrm{Cu}, \mathrm{Cd}, \mathrm{Pb}$ and $\mathrm{Ni}$ were significantly higher in the outlet than inlet water of the dam during both wet and dry seasons $(\mathrm{p} \leq 0.006)$ except for $\mathrm{Cu}$ during the wet season (Table 2 ). This may be attributed to bio accumulations and deposition of heavy metals on bottom sediments of this wetland. Ndeda [25] also studied accumulation of heavy metals in hydrophytes and sediment of Nairobi dam and revealed that heavy metals accumulate in sediments and hydrophytes within wetlands.

\section{Conclusion}

The range of heavy metal(s) accumulation in dam's water within all the seven sampling sites were $0.28 \pm 0.15-17.51 \pm 0.11 \mathrm{mg} / \mathrm{L}$. The sequence of metals accumulation was $\mathrm{Pb}>\mathrm{Cd}>\mathrm{Cu}>\mathrm{Ni}$, which were significantly higher in Nairobi dam water $(\mathrm{p}<0.0001)$ during the dry compared to wet season. This shows that the dry season gives the worst case scenario of pollution. There was significant reduction $(p \leq 0.006)$ of heavy metal(s) contaminations in the outlet water as compared to inlet waters in the wet than dry season. This indicates that pollution removal mechanisms takes place in water bodies. Based on WHO; EU and KEBS $[3,19,20]$ standards for drinking water, Nairobi dam water is highly polluted by $\mathrm{Pb}, \mathrm{Cd}, \mathrm{Cu}$ and Ni. Therefore, the water is not good for human and animal drinking and also for any agricultural activities.

\section{References}

[1]. Ogoyi, D. O., Mwita, C. J., Nguu, E. K. \& Shiundu, P. M. (2011). Determination of heavy metal content in water, sediment and microalgae from Lake Victoria, East Africa, The Open Environmental Engineering Journal, 4, 156-161.

[2]. Roberts, JR. (1999). Metal toxicity in children. In: Training Manual on Pediatric Environmental Health. Children's Environmental Health: Emeryville, CA.

[3]. WHO. (2011). Guidelines for drinking-water quality. Fourth edition, Malta: Gutenberg. ISBN 9789241548151.

[4]. Kennish, M. J. (1992). Ecology of Estuaries: Anthropogenic Effects, Boca Raton, Florida,USA: CRC Press pp. 494.

[5]. Connell, B.S., Cox, M. \& Singer, I. (1984): Nickel and Chromium In: Disorders of minerals metabolism, F. Brunner and J. W. Coburn. [Eds.], Academic press: New York. pp. 472-532.

[6]. Imam, T. S. (2012). Assessment of heavy metals concentrations in the surface water of bompai-jakara drainage basin, kano state, northern Nigeria. Bayero Journal of Pure and Applied Sciences, 5(1), 103-108.

[7]. Berner, E. K. \& Berner, R. A. (1987). The global water cycle: Geochemistry and Environment: Englewood Cliffs, NJ: PrenticeHall, Inc., pp. 142-155.

[8]. Bricker, O. P. \& Jones, B. F. (1995). Main factors affecting the composition of natural waters, In: Trace Metals in Natural Waters: Ch. 1, B. Salbu, E. Steines. [Eds.], CRC Press, pp. 1-19.

[9]. Linnik, P. M. \& Zubenko, I. B. (2000). Role of bottom sediments in the secondary pollution of aquatic environments by heavy metal compounds. Lakes and Reservoir: Research and Management, 5, 11-21.

[10]. UNEP \& IUCN. (2002). Baseline Survey and Environmental Impact Assessment. Nairobi.

[11]. APHA (2005). Standard methods for the Examination of water and waste water. 20 ${ }^{\text {th }}$ Ed. America Public Health Association, Washington DC, USA.

[12]. UNEP. (2003). NRBP-Phase II: Pollution Monitoring and Assessment. United Nations Environment Programme. Nairobi.

[13]. Kumar, N. J., Das, M., Mukherji, R. \& Kumar, R. N. (2012). Trace metal contents in water, sediment and hydrophytes at a freshwater wetland in central gujarat, india. Bulletin of Environmental and Scientific Research, 1(1), 16-24.

[14]. Abida, B., HariKrishna, S. \& Irfanulla, K. (2009). Analysis of heavy metals in water, sediments and fish samples of Madivala lakes of Bangalore, Karnataka. International Journal of ChemTech Research, 1(2), 245-249

[15]. Samir, M. S. \& Shaker. M. I. (2008). Assessment of heavy metals pollution in water and sediments and their effect on oreochromis niloticus in the northern delta lakes, Egypt. 8th International Symposium on Tilapia in Aquaculture. Egypt.

[16]. Oyekunle, J. A. O., Ogunfowokan, A. O., Olutona, G. O., Atoyebi, A. O. \& Lawal, A. (2013). Speciation Study of Heavy Metals in Water and Sediments from Asunle River of the Obafemi Awolowo University, Ile-Ife, Nigeria. International Journal of Environmental Protection, 3(3), 6-16.

[17]. Rai, P. K. (2008). Heavy metals in water, sediments and wetland plants in an aquatic ecosystem of tropical industrial region, India. Springer Science: Environ Monit Assess, 158, 433-457.

[18]. Olatunde, S. O. \& Oladele, O. (2012). Determination of selected heavy metals in inland fresh water of lower River Niger drainage in North Central Nigeria. African Journal of Environmental Science and Technology, 6(10), 403-408.

[19]. EU. (1998). Council Directive 98/83/EC on the Quality of Water Intended for Human Consumption. Official Journal of the European Communities,330/32, 11.

[20]. KEBS. (2007). Drinking Water - Specification, Part 1: The Requirements for Drinking Water.( ${ }^{\text {rd }}$ ed.), Nairobi: KEBS. (KS 459$1: 2007)$. 
[21]. Mwangi, J. K., Thiong'o, G. T. \& Gathenya, J. M. (2011). Assessment of the water quality status of Sasumua Watershed, Kenya. Msc. Thesis, Jomo Kenyatta University of Agriculture and Technology, Nairobi, Kenya.

[22]. Mondol, N., Chamon, A. S., Faiz, B. \& Elahi, D. S. F. (2011). Seasonal variation of heavy metal concentrations in water and plant samples around tejgaon industrial area of bangladesh. Journal of Bangladesh Academy of Sciences, 35(1), 19-41.

[23]. Schulz, R. \& Peall, S. C. (2001). Effectiveness of a constructed wetland for retention of nonpoint-source pesticide pollution in the Lourens River Catchment, South Africa. Environ. Sci. Technol. 35, 422-426.

[24]. Schiffer, D. M. (1989). Effects of Highway Runoff on The Quality of Water and Bed Sediments of Two Wetlands in Central Florida. U.S. Geological Survey-Water Resources Investigations Report 88-4200. Tallahassee, Florida.

[25]. Ndeda, L. A., Manohar, S. \& Macharia, G. (2014). Assessment of heavy metals in hydrophytes, water and sediments of Nairobi dam, Kenya. M. ENV. S. Thesis, Kenyatta University, Nairobi, Kenya.

Appendix I: Maximum permissible levels of heavy metals in drinking water according to WHO, EU and KEBS Standards

\begin{tabular}{lllll}
\hline & Copper & Cadmium & Lead & Ni \\
\hline WHO(2011) & $2 \mathrm{mg} / \mathrm{L}$ & $0.003 \mathrm{mg} / \mathrm{L}$ & $0.01 \mathrm{mg} / \mathrm{L}$ & $0.07 \mathrm{mg} / \mathrm{L}$ \\
EU (1998) & $2 \mathrm{mg} / \mathrm{L}$ & $0.005 \mathrm{mg} / \mathrm{L}$ & $0.01 \mathrm{mg} / \mathrm{L}$ & $0.02 \mathrm{mg} / \mathrm{L}$ \\
& & & & \\
KEBS(2007) & $1 \mathrm{mg} / \mathrm{L}$ & $0.003 \mathrm{mg} / \mathrm{L}$ & $0.01 \mathrm{mg} / \mathrm{L}$ & $0.02 \mathrm{mg} / \mathrm{L}$ \\
Study results & $3.95 \mathrm{mg} / \mathrm{L}$ & $4.44 \mathrm{mg} / \mathrm{L}$ & $12.69 \mathrm{mg} / \mathrm{L}$ & $1.66 \mathrm{mg} / \mathrm{L}$ \\
\hline
\end{tabular}

